\title{
Intracardiac metastasis of high-grade sarcoma of the neck causing right ventricular outflow obstruction
}

\author{
Braghadheeswar Thyagarajan, Dileep Unnikrishnan, Shil Patel, \\ Sayee Sundar Alagusundaramoorthy
}

Department of Internal Medicine, Monmouth Medical Center, Long Branch, New Jersey, USA

\section{Correspondence to} Dr Braghadheeswar Thyagarajan,

bragmd@gmail.com

Accepted 19 May 2016
CrossMark

To cite: Thyagarajan $B$, Unnikrishnan D, Patel $S$, et al. BMJ Case Rep Published online: [please include Day Month Year] doi:10.1136/bcr-2016215455

\section{DESCRIPTION}

A 71-year-old man with a medical history significant for high-grade pleomorphic undifferentiated soft tissue sarcoma of the neck and multiple lung metastases presented to the emergency room, with exertional dyspnoea. He was actively receiving palliative radiation at the time of presentation as his tumour was deemed untreatable by his oncologist. Physical examination revealed a cachectic man in mild respiratory distress, at rest. A firm, non-tender $8 \times 8 \mathrm{~cm}$ mass was palpated in the suboccipital area of his neck. On auscultation, there were bilateral scattered rhonchi, but no crackles. Cardiovascular examination revealed a grade $3 / 6$ ejection systolic murmur, heard loudest in the pulmonic area, which worsened on inspiration but did not radiate to other areas.

Chest X-ray displayed bilateral pleural effusions and multiple new metastatic lesions, as well as earlier metastatic lesions that were enlarged as compared to those seen on the patient's prior CT chest scans. The initial differential diagnosis was pulmonary embolism on a background of hypercoagulability secondary to malignancy. A CT scan of the chest with contrast study was subsequently performed to assess for a pulmonary embolism but was negative for any central or peripheral pulmonary emboli. However, the study revealed a filling defect in the right ventricle (figure 1) (figure 2). A transthoracic echo was then employed to further characterise this filling defect and it demonstrated a large right ventricular mass encroaching on the right ventricular (RV) outflow tract. RV pressure was noted to be $>60 \mathrm{~mm} \mathrm{Hg}$ with normal left ventricular systolic function. (figure 3) (figure 4) (figure 5). Given the large size and inoperable nature of the mass, and his overall status and outlook, the patient was referred to hospice for comfort care.

Metastatic cardiac tumours are more common than primary cardiac tumours. ${ }^{1}$ The most common

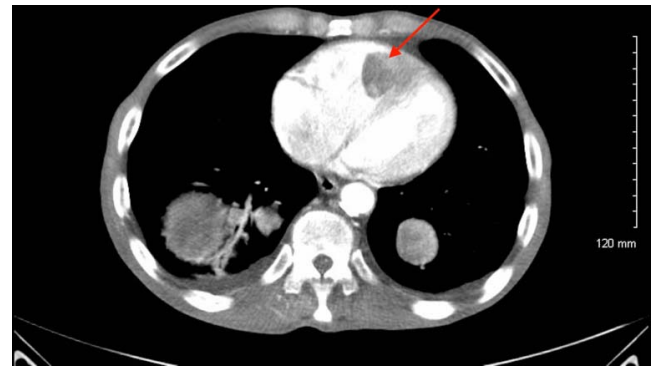

Figure 1 Axial chest CT with contrast showing complex filling defect in the right ventricle of the heart.

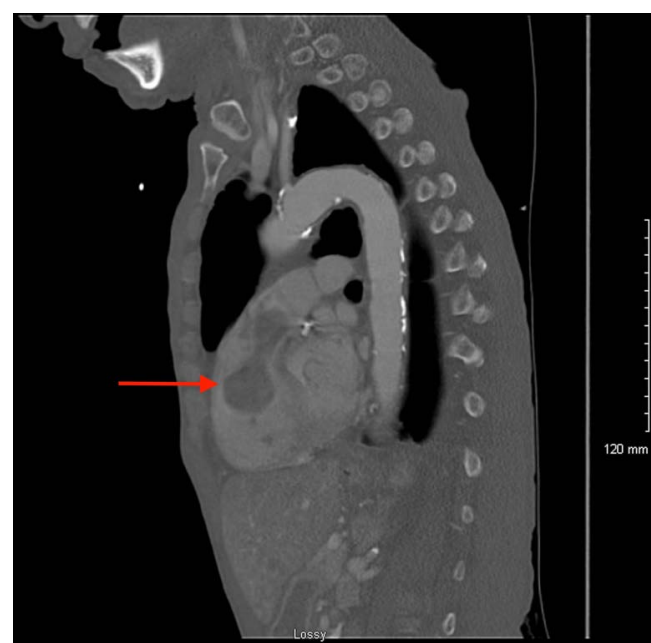

Figure 2 Sagittal chest CT with contrast showing complex filling defect in the right ventricle of the heart.

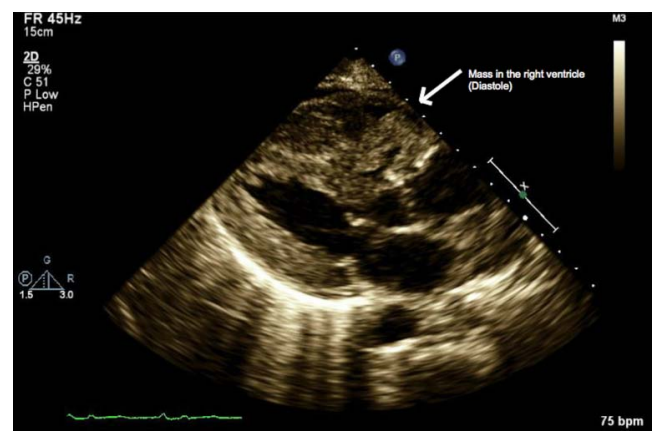

Figure 3 Parasternal long axis view of two-dimensional transthoracic echocardiography showing large mass in the right ventricle (diastole).

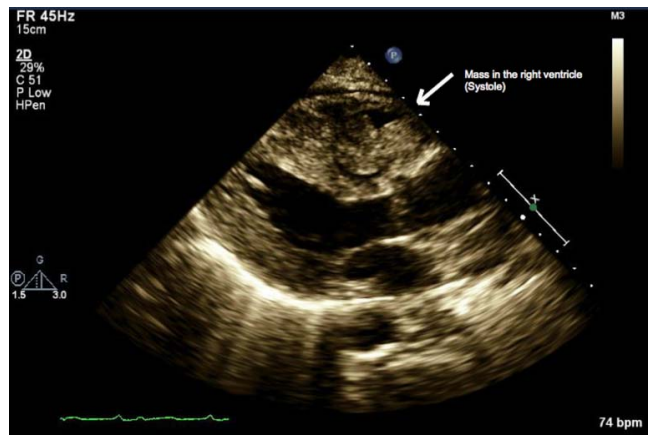

Figure 4 Parasternal long axis view of two-dimensional transthoracic echocardiography showing large mass in the right ventricle (systole). 


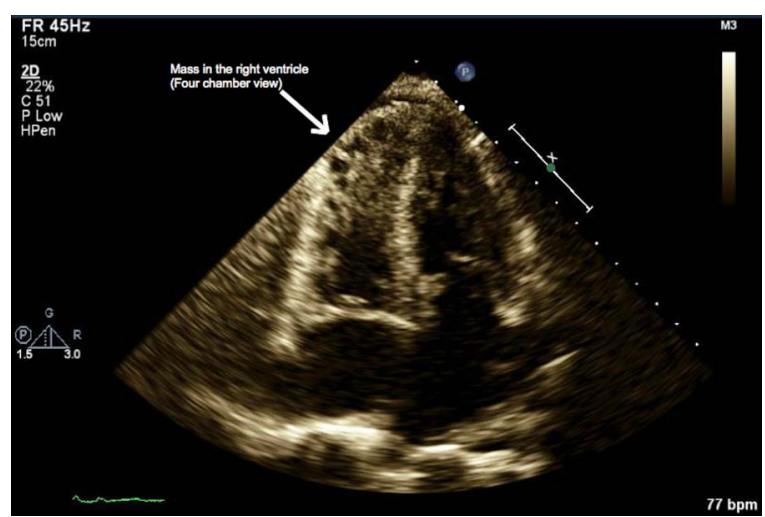

Figure 5 Apical four-chamber view of two-dimensional transthoracic echocardiography showing large complex mass in the right ventricle.

clinical presentation is congestive heart failure. Other associated findings include arrhythmias, pericardial effusions, cardiac tamponades, restrictive pericarditis and diffuse myocardial metastases. ${ }^{2}$ Symptoms secondary to outflow tract obstruction from the intraluminal metastases, as in this case, are quite rare. A variety of imaging modalities such as transthoracic echocardiography (TTE), transoesophageal echocardiography, CT imaging and MRI can be used for diagnosis. Still, TTE is considered the primary tool in the accurate diagnosis of site and nature of tumours due to its ease and availability. ${ }^{3}$

\section{Learning points}

- Cardiac metastases causing aortic or pulmonary outflow obstruction, although rare in occurrence, should be a consideration in anyone with sarcomatous malignancies presenting with exertional dyspnoea.

- Echocardiography, an easily used tool, remains critical in the diagnosis of cardiac tumours.

- In known cases of soft tissue sarcoma, periodic screening with echocardiography will help in early diagnosis and treatment of the cardiac metastases.

Acknowledgements Department of Internal Medicine, Monmouth Medical Center, USA.

Competing interests None declared.

Patient consent Obtained.

Provenance and peer review Not commissioned; externally peer reviewed.

\section{REFERENCES}

1 Kim CH, Dancer JY, Coffey D, et al. Clinicopathologic study of 24 patients with primary cardiac sarcomas: a 10-year single institution experience. Hum Pathol 2008;39:933-8.

2 Hallahan DE, Vogelzang NJ, Borow KM, et al. Cardiac metastases from soft-tissue sarcomas. J Clin Oncol 1986;4:1662-9.

3 Auger D, Pressacco J, Marcotte F, et al. Cardiac masses: an integrative approach using echocardiography and other imaging modalities. Heart 2011;97:1101-9.

Copyright 2016 BMJ Publishing Group. All rights reserved. For permission to reuse any of this content visit http://group.bmj.com/group/rights-licensing/permissions.

BMJ Case Report Fellows may re-use this article for personal use and teaching without any further permission.

Become a Fellow of BMJ Case Reports today and you can:

- Submit as many cases as you like

- Enjoy fast sympathetic peer review and rapid publication of accepted articles

- Access all the published articles

- Re-use any of the published material for personal use and teaching without further permission

For information on Institutional Fellowships contact consortiasales@bmjgroup.com

Visit casereports.bmj.com for more articles like this and to become a Fellow 